\title{
Stackebrandtia nassauensis gen. nov., sp. nov. and emended description of the family Glycomycetaceae
}

\author{
Correspondence \\ D. P. Labeda \\ labedadp@mail.ncaur.usda.gov
}

\section{P. Labeda ${ }^{1}$ and R. M. Kroppenstedt ${ }^{2}$}

\author{
${ }^{1}$ Microbial Genomics and Bioprocessing Research Unit, National Center for Agricultural \\ Utilization Research, Agricultural Research Service, 1815 N. University Street, US Department \\ of Agriculture, Peoria, IL 61604, USA \\ ${ }^{2} \mathrm{DSMZ}$ - German Collection of Microorganisms and Cell Cultures, Braunschweig, Germany
}

During the course of a 16S rRNA gene sequence phylogenetic evaluation of putative Glycomyces strains, it was noted that strain NRRL B-16338 is phylogenetically nearest to the genus Glycomyces but apparently is not a member of this or any of the other currently described actinomycete genera. The strain was subjected to a polyphasic study using standard methods for chemotaxonomic, morphological and physiological evaluation. The strain exhibited chemotaxonomic characteristics distinct from Glycomyces in spite of having 16S rRNA gene sequence similarity of $92 \%$ with the described species of this genus. The whole-cell sugar pattern of NRRL B-16338 ${ }^{\top}$ consisted of ribose and inositol, with traces of arabinose and mannose. The phospholipids observed were phosphatidylglycerol and diphosphatidylglycerol and menaquinones consisting of MK-10 $\left(\mathrm{H}_{4}\right), M K-10\left(\mathrm{H}_{6}\right), M K-11\left(\mathrm{H}_{4}\right)$ and $\mathrm{MK}-11\left(\mathrm{H}_{6}\right)$. A significant quantity $(14.5 \%)$ of $17: 0$ anteiso 2-hydroxy fatty acid was observed in the fatty acid profile of this strain. These characteristics clearly differentiate NRRL B-16338 ${ }^{\top}$ from members of the genus Glycomyces and it is proposed that the strain represents a new genus within the family Glycomycetaceae to be called Stackebrandtia gen. nov. The description of this family is emended to permit its inclusion. It is proposed that the type species of the genus should be named Stackebrandtia nassauensis. The type strain LLR-4OK-21 ${ }^{\top}\left(=\mathrm{NRRL} \mathrm{B}-16338^{\top}=\mathrm{DSM} 44728^{\top}\right)$ was isolated from a soil sample from Nassau, Bahamas.
During the course of a phylogenetic evaluation of putative strains of Glycomyces based on 16S rRNA gene sequences (Labeda \& Kroppenstedt, 2004), strain LLR-40K-21 ${ }^{\mathrm{T}}$ ( $=$ NRRL B- $16338^{\mathrm{T}}=\mathrm{DSM} 44728^{\mathrm{T}}$ ), isolated by Mary P. Lechevalier from a soil sample collected on the road side in Nassau, Bahamas, was found to be phylogenetically most closely related to the genus Glycomyces, but clearly not a member this genus. The strain was subjected to a polyphasic study using standard methods for chemotaxonomic and morphological evaluation. In addition to strain NRRL $\mathrm{B}-16338^{\mathrm{T}}$, the type strains of all described Glycomyces species were included in this study, i.e. Glycomyces rutgersensis NRRL B-16106 ${ }^{\mathrm{T}}$, G. harbinensis NRRL $15337^{\mathrm{T}}$, G. tenuis NRRL B-16895 ${ }^{\mathrm{T}}, G$. algeriensis NRRL B-16327 ${ }^{\mathrm{T}}, \quad$ G.

Published online ahead of print on 1 April 2005 as DOI 10.1099/ ijs.0.63496-0.

\section{Abbreviation: DAP, 2,6-diaminopimelic acid.}

The GenBank/EMBL/DDBJ accession number for the 16S rRNA gene sequence of Stackebrandtia nassauensis sp. nov. NRRL B-16338 ${ }^{\top}$ is AY650268. arizonensis NRRL B-16153 ${ }^{\mathrm{T}}$ and G. lechevalieriae NRRL B- $16149^{\mathrm{T}}$.

The strain was cultivated on NZ-amine starch agar (DSMZ medium no. 554) at $28^{\circ} \mathrm{C}$. Morphological observations were made on yeast extract-malt extract agar (ISP-2), inorganic salts-starch agar (ISP-4), glycerol-asparagine agar (ISP-5) (Shirling \& Gottlieb, 1966), Czapek's sucrose agar (Pridham \& Lyons, 1980) and DSMZ medium no. 554 (DSMZ, 2001).

For the analyses of fatty acids, about $40 \mathrm{mg}$ of cells was scraped from agar plates. For the other chemical analyses, cells were grown in liquid medium and harvested by centrifugation. Chemotaxonomic analyses of strains for polar lipids, menaquinones and fatty acids were performed using previously described methods (Grund \& Kroppenstedt, 1989; Minnikin et al., 1984; Sasser, 1990). Cell-wall diamino acid isomer was determined by the method of Staneck \& Roberts (1974) and whole-cell sugar content was determined as alditol acetates by the method of Saddler et al. (1991). The acyl type of the muramic acid in the cell wall was determined by the method of Uchida \& Aida (1977). 
Genomic DNA for sequencing of the 16S rRNA gene was isolated from growth on DSMZ medium no. 554 plates using UltraClean microbial DNA isolation kits (Mo Bio Laboratories) and then amplified and sequenced following previously described procedures (Labeda \& Kroppenstedt, 2000) The 16S rRNA gene sequence was deposited in GenBank with the accession number AY650268. A phylogenetic tree was constructed according to the neighbourjoining method of Saitou \& Nei (1987) and the stability of the groupings was estimated by bootstrap analysis (Felsenstein, 1989). The $\mathrm{G}+\mathrm{C}$ content of the DNA was determined by HPLC according to Mesbah et al. (1989).

Physiological tests, including production of acid from carbohydrates, utilization of organic acids and hydrolysis and decomposition of adenine, guanine, hypoxanthine, tyrosine, xanthine, casein, aesculin, urea and hippurate, were evaluated using the media of Gordon et al. (1974). Phosphatase activity was measured using the method of Kurup \& Schmitt (1973). The temperature range for growth was determined on slants of DSMZ Medium No. 554.

Phylogenetic analysis clearly demonstrated that strain NRRL B-16338 ${ }^{\mathrm{T}}$ belongs to the order Actinomycetales (Stackebrandt et al., 1997) and is well separated from all Glycomyces type strains (16S rRNA gene sequence similarity to the Glycomyces species studied is only $92 \%$ ) that represent the nearest phylogenetic neighbours (Fig. 1).
Evaluation of the data with several other phylogenetic algorithms, including maximum-parsimony and maximumlikelihood (Felsenstein, 1989), provided dendrograms that exhibited a stable relationship between NRRL B- $16338^{\mathrm{T}}$ and the species within the genus Glycomyces. The exact placement of the suborder Glycomycineae within the class Actinobacteria is somewhat different for each computational method, possibly reflecting the small number of taxa available and sequenced within this suborder.

Chemotaxonomic data supported the separation of strain NRRL B- $16338^{\mathrm{T}}$ from the genus Glycomyces, as can be seen in Table 1. The whole-cell sugar pattern for strain NRRL $\mathrm{B}-16338^{\mathrm{T}}$ consists of ribose and inositol, with traces of arabinose and mannose, whereas in all Glycomyces strains, ribose, xylose mannose and galactose are found as diagnostic sugars. NRRL B-16338 ${ }^{\mathrm{T}}$ and all of the Glycomyces type strains were found to contain $\mathrm{N}$-glycolylmuramic acid. Strain NRRL B- $16338^{\mathrm{T}}$ and the Glycomyces strains synthesize phosphatidylglycerol and diphosphatidylglycerol but NRRL B- $16338^{\mathrm{T}}$ exhibits two additional unknown phospholipids; all Glycomyces strains are rich in sugar-containing phospholipids such as phosphatidylinositolmannosides and two phosphoglycolipids of unknown structure. The fatty acid pattern clearly separates NRRL B- $16338^{\mathrm{T}}$ from the Glycomyces strains by the occurrence of 10-methyl-branched heptadecanoic acid and iso-branched 2-hydroxy fatty acids which are missing in Glycomyces (Table 2). The

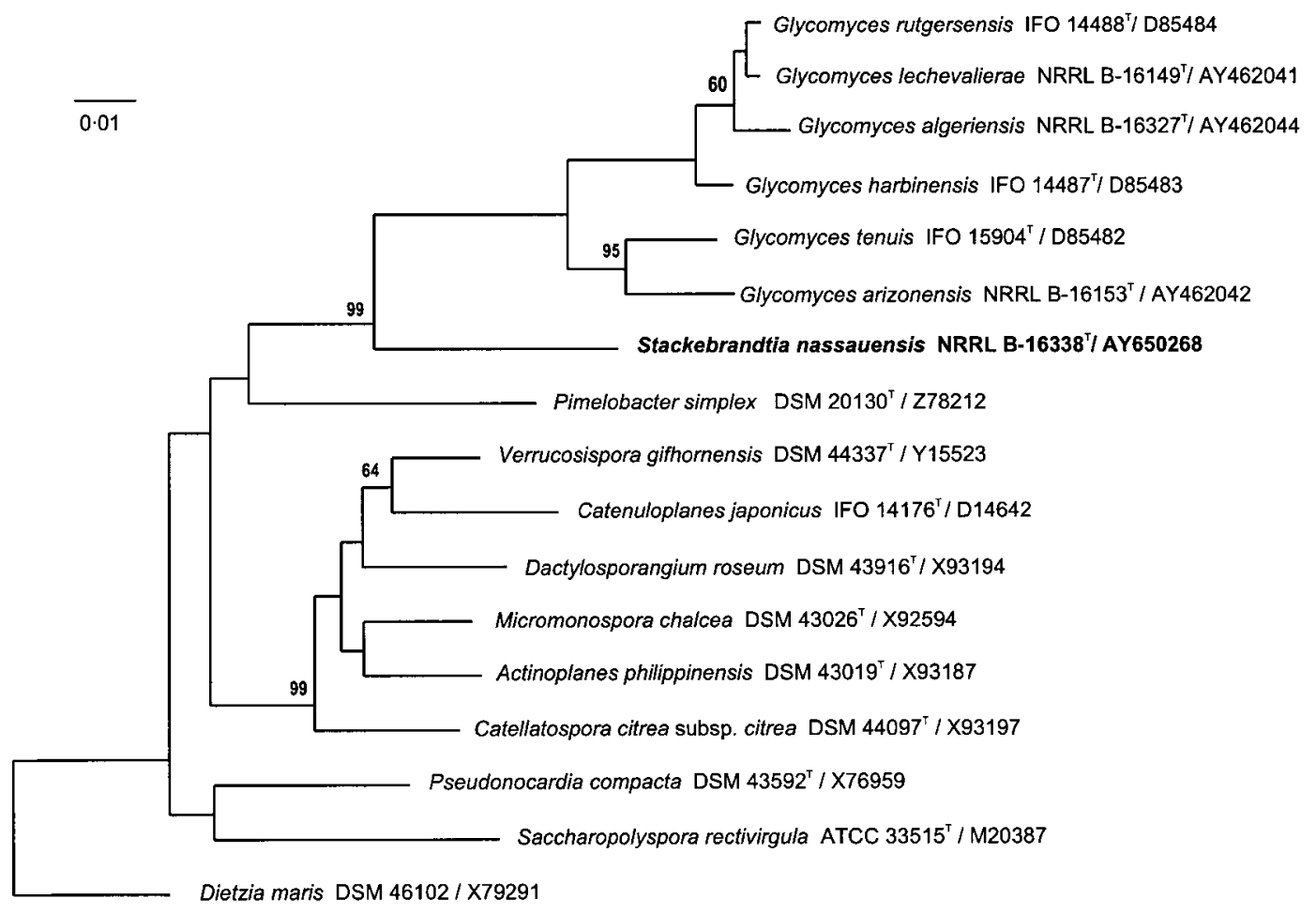

Fig. 1. Phylogenetic tree of the proposed genus Stackebrandtia and near neighbours calculated from 16S rRNA gene sequences using Kimura's evolutionary distance method (Kimura, 1980) and the neighbour-joining method of Saitou \& Nei (1987). Bar, 0.01 nucleotide substitutions per site. 
Table 1. Comparison of chemotaxonomic characteristics of Stackebrandtia and Glycomyces

Abbreviations: PI, Phosphatidylinositol; PIM, phosphatidylinositolmannosides; PG, phosphatidylglycerol;

DPG, diphosphatidylglycerol; $\mathrm{PGL}_{1,2}$, unknown phosphoglycolipids; $\mathrm{PL}_{1,2}$, unknown phospholipids.

\begin{tabular}{|llll|}
\hline & DAP isomer & \multicolumn{1}{c|}{ Whole-cell sugars } & \multicolumn{1}{c|}{ Polar lipids } \\
\hline Stackebrandtia & meso-DAP & Inositol, ribose & PG, DPG, PL, $\mathrm{PL}_{2}$ \\
Glycomyces & meso-DAP & Galactose, mannose, ribose, xylose & PIM, PI, PG, DPG, PGL, $\mathrm{PGL}_{2}$ \\
\hline
\end{tabular}

menaquinone pattern of NRRL B- $16338^{\mathrm{T}}$, where the predominant menaquinones are $\mathrm{MK}-10\left(\mathrm{H}_{4}\right), \mathrm{MK}-10\left(\mathrm{H}_{6}\right)$, MK-11 $\left(\mathrm{H}_{4}\right)$ and MK-11( $\left.\mathrm{H}_{6}\right)$, is also different from that of the genus Glycomyces, where the pattern appears almost species-specific but consists of menaquinones with 9, 10, 11 or 12 isoprene units with various degrees of hydrogenation (Table 3).

The gross morphological characteristics of NRRL B-16338 are stated in the description below. Fragmentation of aerial or substrate mycelium into spore-like bodies has not been observed on any of the media studied. Moreover,

Table 2. Fatty acid profiles of Stackebrandtia and Glycomyces

Species: 1, Stackebrandtia nassauensis NRRL B-16338 ${ }^{\mathrm{T}}$; 2, Glycomyces algeriensis NRRL B- $16327^{\mathrm{T}}$; 3, G. arizonensis NRRL B$16153^{\mathrm{T}}$; 4, G. harbinensis NRRL $15337^{\mathrm{T}}$; 5 , G. lechevalierae NRRL B- $16149^{\mathrm{T}}$; 6, G. rutgersensis NRRL B- $16106^{\mathrm{T}}$; 7, G. tenuis NRRL B- $16895^{\mathrm{T}}$.

\begin{tabular}{|c|c|c|c|c|c|c|c|}
\hline Fatty acid & 1 & 2 & 3 & 4 & 5 & 6 & 7 \\
\hline $14: 0$ iso & - & $2 \cdot 04$ & $3 \cdot 13$ & $1 \cdot 51$ & $2 \cdot 86$ & $2 \cdot 37$ & $2 \cdot 21$ \\
\hline $14: 0$ & - & - & - & $0 \cdot 49$ & $0 \cdot 45$ & $0 \cdot 61$ & - \\
\hline $15: 0$ iso & $8 \cdot 70$ & $14 \cdot 41$ & $7 \cdot 18$ & $11 \cdot 26$ & $14 \cdot 77$ & $19 \cdot 90$ & $13 \cdot 95$ \\
\hline $15: 0$ anteiso & $2 \cdot 89$ & $27 \cdot 52$ & $25 \cdot 36$ & $15 \cdot 11$ & $32 \cdot 52$ & $30 \cdot 95$ & $33 \cdot 20$ \\
\hline $15: 1$ & $0 \cdot 84$ & - & - & - & - & - & - \\
\hline $15: 0$ & $0 \cdot 64$ & - & - & $0 \cdot 41$ & $2 \cdot 01$ & $2 \cdot 98$ & $2 \cdot 07$ \\
\hline $16: 1$ iso & $2 \cdot 11$ & $4 \cdot 37$ & $11 \cdot 53$ & $10 \cdot 34$ & $4 \cdot 14$ & $4 \cdot 37$ & $2 \cdot 59$ \\
\hline $16: 0$ iso & $8 \cdot 72$ & $10 \cdot 90$ & $22 \cdot 69$ & $17 \cdot 83$ & $16 \cdot 19$ & $12 \cdot 52$ & $16 \cdot 00$ \\
\hline $16: 1$ cis 7 & $0 \cdot 53$ & - & - & - & - & - & - \\
\hline $16: 1$ cis 9 & $3 \cdot 17$ & - & - & $0 \cdot 62$ & - & - & - \\
\hline $16: 0$ & $0 \cdot 67$ & - & $1 \cdot 34$ & $2 \cdot 03$ & $1 \cdot 31$ & $1 \cdot 61$ & $1 \cdot 92$ \\
\hline 16:0 10-methyl & $9 \cdot 07$ & - & - & - & - & - & - \\
\hline $17: 1$ iso & $0 \cdot 58$ & - & - & - & - & - & - \\
\hline $17: 1$ anteiso & $1 \cdot 70$ & $12 \cdot 33$ & $8 \cdot 75$ & $12 \cdot 66$ & $5 \cdot 15$ & $6 \cdot 13$ & $3 \cdot 62$ \\
\hline $17: 0$ iso & $9 \cdot 02$ & $2 \cdot 85$ & $1 \cdot 01$ & $1 \cdot 34$ & $1 \cdot 36$ & $0 \cdot 98$ & $1 \cdot 58$ \\
\hline $17: 0$ anteiso & $26 \cdot 86$ & $25 \cdot 59$ & $19 \cdot 01$ & $26 \cdot 41$ & $19 \cdot 24$ & $16 \cdot 82$ & $22 \cdot 86$ \\
\hline $17: 1$ cis 9 & $1 \cdot 84$ & - & - & - & - & $0 \cdot 42$ & - \\
\hline $17: 0$ & - & - & - & - & - & $0 \cdot 34$ & - \\
\hline 17:0 10-methyl & $1 \cdot 44$ & - & - & - & - & - & - \\
\hline 16:0 2-hydroxy & $4 \cdot 22$ & - & - & - & - & - & - \\
\hline 17:0 2-hydroxy & $2 \cdot 45$ & - & - & - & - & - & - \\
\hline $\begin{array}{c}\text { 17:0 anteiso } \\
\text { 2-hydroxy }\end{array}$ & $14 \cdot 52$ & - & - & - & - & - & - \\
\hline
\end{tabular}

observations of wet mounts of substrate and aerial mycelium from various media by phase-contrast light microscopy have never revealed any motile spores. Aerial mycelium has been observed twisting into a spiral morphology on yeast extract-malt extract agar (Fig. 2), while observations of growth on Czapek's sucrose agar (not shown) have revealed regions of aerial mycelia that appear almost ready to fragment into spores, although the latter process has never been found.

The physiological properties of the strain are summarized in the formal species description below.

On the basis of phylogenetic position and novel chemotaxonomy, strain NRRL B-16338 ${ }^{\mathrm{T}}$ is clearly not a member of the genus Glycomyces and therefore a new genus is proposed for this strain, to be named Stackebrandtia. The type species of Stackebrandtia is designated Stackebrandtia nassauensis. This genus may well represent a new family within the

Table 3. Menaquinone content in Stackebrandtia and Glycomyces species

Values are percentages of total menaquinones. Abbreviations are exemplified by MK- $9\left(\mathrm{H}_{4}\right)$, a menaquinone which has two of the nine isoprene units hydrogenated. Species: 1, Stackebrandtia nassauensis NRRL B-16338 ${ }^{\mathrm{T}}$; 2, Glycomyces algeriensis NRRL B$16327^{\mathrm{T}}$; 3, G. arizonensis NRRL B-16153 ${ }^{\mathrm{T}}$; 4, G. harbinensis NRRL $15337^{\mathrm{T}}$ (determined by mass spectrometry; data from Labeda et al., 1985); 5, G. lechevalierae NRRL B-16149 ${ }^{\mathrm{T}}$; 6, G. rutgersensis NRRL B-16106 ${ }^{\mathrm{T}}$ (determined by mass spectrometry; data from Evtushenko et al., 1991; Labeda et al., 1985); 7, G. tenuis NRRL B- $16895^{\mathrm{T}}$ (determined by mass spectrometry; data from Evtushenko et al., 1991). TR, Trace amount.

\begin{tabular}{|c|c|c|c|c|c|c|c|}
\hline Menaquinone & 1 & 2 & 3 & 4 & 5 & 6 & 7 \\
\hline MK-9 $\left(\mathrm{H}_{6}\right)$ & - & - & - & - & - & - & \pm \\
\hline MK-10 & - & 23 & - & - & 17 & - & - \\
\hline MK-10 $\left(\mathrm{H}_{2}\right)$ & - & - & 18 & + & 21 & + & - \\
\hline MK-10 $\left(\mathrm{H}_{4}\right)$ & 30 & - & 52 & - & 11 & - & - \\
\hline MK-10 $\left(\mathrm{H}_{6}\right)$ & 16 & - & $\mathrm{TR}$ & + & - & \pm & + \\
\hline MK-11 & - & 65 & - & - & 24 & - & - \\
\hline MK-11 $\left(\mathrm{H}_{2}\right)$ & - & - & 9 & - & 19 & - & - \\
\hline MK-11(H4) & 31 & - & 22 & - & 8 & - & - \\
\hline $\operatorname{MK} 11\left(\mathrm{H}_{6}\right)$ & 23 & - & - & - & - & - & + \\
\hline MK-12 & - & 12 & - & - & TR & - & - \\
\hline
\end{tabular}




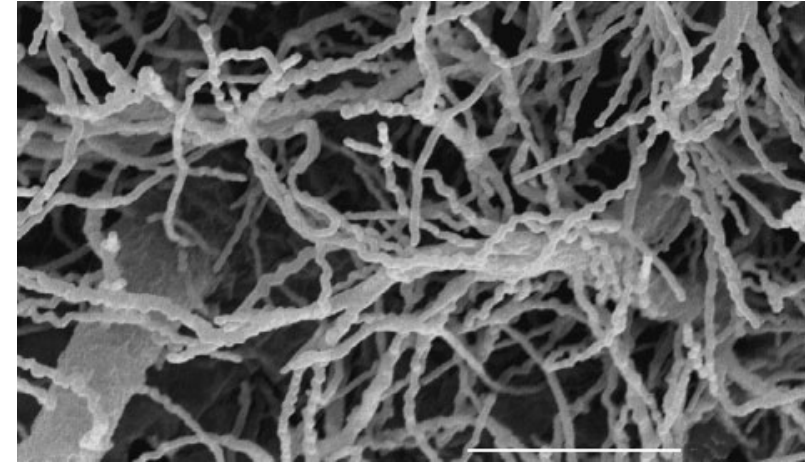

Fig. 2. Scanning electron micrograph of 21-day growth of Stackebrandtia nassauensis NRRL B-16338 ${ }^{\top}$ on ISP-2 agar. Bar, $10 \mu \mathrm{m}$.

suborder Glycomycineae Rainey et al. 1997, but it is premature to base this proposal on a genus containing one species. The description of the family Glycomycetaceae is therefore emended to permit inclusion of the genus Stackebrandtia.

\section{Description of Stackebrandtia gen. nov.}

Stackebrandtia (Stack.e.brandt'i.a. N.L. fem. n. Stackebrandtia named for Erko Stackebrandt, a German microbiologist who has contributed significantly to the molecular systematics of prokaryotes, including actinobacteria).

Aerobic. Gram-positive, non-motile actinomycetes. Branched substrate mycelium (approx. $0.5 \mu \mathrm{m}$ in diameter) and, on some media, aerial mycelia are produced. Mycolic acids are absent. Catalase-positive. Contains mesodiaminopimelic acid as the diamino acid. Cell walls contain $\mathrm{N}$-glycolylmuramic acid. The whole-cell sugar pattern consists of ribose and inositol, with traces of arabinose and mannose. The phospholipid pattern consists of phosphatidylglycerol, diphosphatidylglycerol and two additional unknown phospholipids. The predominant menaquinones are MK-10 $\left(\mathrm{H}_{4}\right)$, MK-10 $\left(\mathrm{H}_{6}\right)$, MK-11( $\left.\mathrm{H}_{4}\right)$ and MK-11( $\left.\mathrm{H}_{6}\right)$. Fatty-acid profile is rich in branched-chain and saturated components including 10-methyl-branched heptadecanoic acid and iso-branched 2-hydroxy fatty acids. Phylogenetically, the nearest neighbour is the genus Glycomyces. Type species is Stackebrandtia nassauensis.

\section{Description of Stackebrandtia nassauensis sp. nov.}

Stackebrandtia nassauensis (nas.sau.en'sis. N.L. fem. adj. nassauensis from Nassau, named after the place of origin of the type strain, Nassau, Providence, Bahamas).

Displays the following properties in addition to those given in the genus description. Pale yellow to pale tan vegetative mycelium; white to yellowish-white aerial hyphae produced on most media, especially ISP-2. Degrades or hydrolyses allantoin, casein, aesculin, gelatin, hypoxanthine, starch and tyrosine. No degradation of adenine or xanthine. Produces phosphatase. Weakly reduces nitrates. Weakly assimilates acetate and malate; does not assimilate benzoate, citrate, lactate, mucate, oxalate, propionate, succinate or tartrate. Acid is produced from arabinose, cellobiose, dextrin, fructose, galactose, glucose, glycerol, lactose, maltose, mannose, melibiose, methyl $\alpha$-D-glucoside, raffinose, rhamnose, salicin, sorbitol, sucrose, trehalose and xylose; no acid produced from adonitol, dulcitol, erythritol, inositol, mannitol, melezitose or methyl $\beta$-xyloside. Temperature range for growth is $15-37^{\circ} \mathrm{C}$. Grows in the presence of $4-9 \% \mathrm{NaCl}$. G $+\mathrm{C}$ content of the DNA is $72 \cdot 4 \mathrm{~mol} \%$ (HPLC).

The type strain, NRRL B-16338 $\left(\right.$ LLR-40K- $21^{\mathrm{T}}=\mathrm{DSM}$ $44728^{\mathrm{T}}$ ), was isolated by Mary Lechevalier from a soil sample from Nassau, Bahamas.

\section{Emended description of the family Glycomycetaceae Rainey et al. 1997}

Glycomycetaceae (Gly.co.my.ce.ta'ceae. N.L. masc. n. Glycomyces type genus of the family; -taceae ending to denote a family; N.L. fem. pl. n. Glycomycetaceae the Glycomyces family).

Aerobic. Gram-positive, non-acid-fast, non-motile actinomycetes comprising the genera Glycomyces and Stackebrandtia. Branched substrate mycelium (approx. $0.35-0.5 \mu \mathrm{m}$ in diameter) and, on some media, aerial mycelia are produced. Mycolic acids are absent. Catalasepositive. Contains meso-diaminopimelic acid as the diamino acid. Cell walls contain $N$-glycolylmuramic acid. Whole-cell sugar pattern contains ribose as a diagnostic sugar along with other genus-specific sugars. Phospholipid content includes phosphatidylglycerol and diphosphatidylglycerol in addition to other genus-specific phospholipids. The 16S rRNA gene sequence pattern of $16 \mathrm{~S}$ rRNA signature nucleotides contains 70-98 (A-U), 415 (C), 449 (C), 534 (G), 681-709 (A-U), 825-875 (G-C), 999-1041 (C-G), 1059-1198 (C-G), 1064-1192 (G-G), 1117-1183 (A-U) and 1309-1328 (C-G). The type genus is Glycomyces.

\section{Acknowledgements}

The able technical assistance of E. N. Hoekstra for physiological characterization, DNA isolation and purification and 16S rRNA gene sequencing is gratefully acknowledged. Names are necessary to report factually on available data; however, the USDA neither guarantees nor warrants the standard of the product and the use of the name by USDA implies no approval of the product to the exclusion of others that may also be suitable.

\section{References}

DSMZ (2001). Catalogue of Strains. Braunschweig: Deutsche Sammlung von Mikroorganismen und Zellkulturen. 
Evtushenko, L. I., Taptykova, S. D., Akimov, V. N., Semyonova, S. A. \& Kalakoutskii, L. V. (1991). Glycomyces tenuis sp. nov. Int J Syst Bacteriol 41, 154-157.

Felsenstein, J. (1989). PHYLIP (Phylogeny Inference Package), version 3.5.1. Distributed by the author. Department of Genome Sciences, University of Washington, Seattle, WA, USA.

Gordon, R. E., Barnett, D. A., Handerhan, J. E. \& Pang, C. H. -N. (1974). Nocardia coeliaca, Nocardia autotrophica, and the nocardin strain. Int J Syst Bacteriol 24, 54-63.

Grund, E. \& Kroppenstedt, R. M. (1989). Transfer of five Nocardiopsis species to the genus Saccharothrix Labeda et al., 1984. Syst Appl Microbiol 12, 267-274.

Kimura, M. (1980). A simple method for estimating evolutionary rates of base substitutions through comparative studies of nucleotide sequences. J Mol Evol 16, 111-120.

Kurup, P. V. \& Schmitt, J. A. (1973). Numerical taxonomy of Nocardia. Can J Microbiol 19, 1035-1048.

Labeda, D. P. \& Kroppenstedt, R. M. (2000). Phylogenetic analysis of Saccharothrix and related taxa: proposal for Actinosynnemataceae fam. nov. Int J Syst Evol Microbiol 50, 331-336.

Labeda, D. P. \& Kroppenstedt, R. M. (2004). Emended description of the genus Glycomyces and description of Glycomyces algeriensis sp. nov., Glycomyces arizonensis sp. nov. and Glycomyces lechevalierae sp. nov. Int J Syst Evol Microbiol 54, 2343-2346.

Labeda, D. P., Testa, R. T., Lechevalier, M. P. \& Lechevalier, H. A. (1985). Glycomyces, a new genus of the Actinomycetales. Int J Syst Evol Microbiol 35, 417-421.

Mesbah, M., Premachandran, U. \& Whitman, W. B. (1989). Precise measurement of the $\mathrm{G}+\mathrm{C}$ content of deoxyribonucleic acid by high-performance liquid chromatography. Int J Syst Bacteriol 39, 159-167.

Minnikin, D. E., O’Donnell, A. G., Goodfellow, M., Alderson, A., Athalye, M., Schaal, K. \& Parlett, J. H. (1984). An integrated procedure for the extraction of bacterial isoprenoid quinones and polar lipids. J Microbiol Methods 2, 233-241.

Pridham, T. G. \& Lyons, A. J. (1980). Methodologies for Actinomycetales with special reference to streptomycetes and streptoverticillia. In Actinomycete Taxonomy, pp. 153-224. Edited by A. Dietz \& D. W. Thayer. Special publication no. 6. Arlington, VA: Society for Industrial Microbiology.

Saddler, G. S., Tavecchia, P., Lociuro, S., Zanol, M., Colombo, E. \& Selva, E. (1991). Analysis of madurose and other actinomycete whole cell sugars by gas chromatography. J Microbiol Methods 14, 185-191.

Saitou, N. \& Nei, M. (1987). The neighbor-joining method: a new method for reconstructing phylogenetic trees. Mol Biol Evol 4, 406-425.

Sasser, M. (1990). Identification of bacteria by gas chromatography of cellular fatty acids. USFCC Newsl 20, 1-6.

Shirling, E. B. \& Gottlieb, D. (1966). Methods for characterization of Streptomyces species. Int J Syst Bacteriol 16, 313-340.

Stackebrandt, E., Rainey, F. A. \& Ward-Rainey, N. L. (1997). Proposal for a new hierarchic classification system, Actinobacteria classis nov. Int J Syst Bacteriol 47, 479-491.

Staneck, J. L. \& Roberts, G. D. (1974). Simplified approach to identification of aerobic actinomycetes by thin-layer chromatography. Appl Microbiol 28, 226-231.

Uchida, K. \& Aida, K. (1977). Acyl type of bacterial cell walls: its simple identification by colorimetric methods. J Gen Appl Microbiol 23, 249-260. 